\title{
BIOCHEMICAL ANALYSIS AND COMPARISON OF SUPERIOR CABBAGE GENOTYPES GROWN IN PLAINS AND HILLS OF KERALA, INDIA
}

\author{
K. Elavarasan ${ }^{1 *}$, S. Soundara Rajan ${ }^{2}$, A. Manoharan ${ }^{3}$, P. B. Pushpalatha ${ }^{4}$ \\ ${ }^{1}$ Extension Inspector, Govt. of India, Regional Coffee Research Station, Coffee Board, Thandgudi, \\ India- 624216 \\ ${ }^{2}$ Department of Plant Pathologist, Asst. Plant Pathologist, Govt. of India, Regional Coffee \\ Research Station, Coffee Board, Thandgudi, India- 624216 \\ ${ }^{3}$ Department of Plant Breeding and Genetics, Plant Breeder, Govt. of India, Regional Coffee \\ Research Station, Coffee Board, Thandgudi, India- 624216 \\ ${ }^{4}$ Department of Processing Technology (Horticulture), College of Horticulture, Kerala Agriculture \\ University, Vallanikara, Thrissur (Kerala) - 680656 \\ *E-mail address: princekau@gmail.com
}

Keywords: Biochemical, cabbages, compared, genotypes, performance

\begin{abstract}
The present study was undertaken to identify the superior cabbage genotype and to examine their physical yield performance among the four cultivated genotypes namely Namdhari Seeds 183, Namdhari Seeds 160, Namdhari Seeds 35 and Tropical Sun Plus, grown in plains and higher altitude of Kerala. Study revealed that significant differences were observed in yield levels of cabbage and it was ranged from $22.6-29.3 \mathrm{~kg} / 16 \mathrm{~m}^{2}$ in hills and $1.27-22.06 \mathrm{~kg} / 16 \mathrm{~m}^{2}$ in plains. Among the cabbage genotypes, NS 183 was found to be the best for hilly region in terms of higher head yield $\left(22.06 \mathrm{Kg} / 16 \mathrm{~m}^{2}\right)$, head weight $(729.6 \mathrm{~g})$, head height $(11.1 \mathrm{~cm})$ and early maturity. Similarly, Tropical Sun Plus exhibited better performance in plains in terms of higher head yield $(22.06 \mathrm{Kg} / 16 \mathrm{~m} 2)$, head weight $(729.6 \mathrm{~g})$ and head height $(11.1 \mathrm{~cm})$. The individual genotype which exhibited the superior performance in hills and plains were selected and compared for the general biochemical characters like Moisture content, acidity, ascorbic acid, protein, phosphorus, calcium and potassium. Finally, the study found that, the genotype grown at hill (Tropical Sun Plus) was recorded a higher biochemical characters than genotype grown in plains (Tropical Sun plus). Similarly, hill grown genotype (NS 183) recorded a higher biochemical characters than the plains grown genotype (NS 183).
\end{abstract}

\section{INTRODUCTION}

Cabbage (Brassica oleracea var. capitata L., $2 \mathrm{n}=2 \mathrm{x}=18$ ) belongs the family Cruciferacea is used as a green leafy vegetable and it termed as head. It is one of the most important Cole crops grown under temperate to tropical climate conditions for its head in more than ninety countries throughout the World (Singh et al., 2010). Cabbage is grown in all over the agro climatic zones of India and accounting for a production of 85.34 lakh tonnes with area of 3.72 lakh hectares (NHB, 2014). It is a rich source of minerals like phosphorus, potassium, calcium, sodium and iron. According to Martinez et al. (2010) conducted study to determine and to compare the values of some physicochemical parameters (Moisture, soluble solids, titratable acidity, $\mathrm{pH}$, protein, ash, vitamin $\mathrm{C}$, total phenolics, chlorogenic acid, caffeic acid, p-coumaric acid, quercitin and chlorophyll) in different edible portions of white cabbages. The mean values of parameters measured in leaves were higher than those measured in stems except for moisture content. Similarly, Jagdish et al. (2009) studied the total phenol content and free radical scavenging activity of methanolic extracts from different brassica vegetables. The total phenol in red cabbage was found and it ranges from 18.7 to $101.30 \mathrm{mg}$ gallic acid equivalent $/ 100 \mathrm{~g}$ of fresh weight of cabbage. The antioxidant activity ranged from 13.1 in red cabbage to $2.8 \mu$ moles trolox equivalents 
per gram in white cabbage fresh sample. The linear regression analysis of data showed a significant positive correlation between total phenolic contents and free radical scavenging capacity. Based on above studies, the challenging biochemical comparative study has taken into account between hills and plains grown genotypes, which was found to be the better genotype in the expression of biochemical characters.

\section{MATERIALS AND METHODS}

Experimental material comprised of four genotypes namely Namdhari Seeds 183, Namdhari Seeds 160, Namdhari Seeds 35 and Tropical Sun Plus. All four cabbage genotypes have simultaneously raised in the plains of Agriculture Research Station, Department of Horticulture, Mannuthy and hills of Orange and Vegetable farm, Nelliyampathy during the winter season of 2009 to 2011. Each genotype was planted in a plot having $8.0 \times 2.0 \mathrm{~m}$ area in randomized block design with five replications. There were 44 plants in each plot planted at $60 \times 60 \mathrm{~cm}$ spacing. All the standard package of practices and plant protection measures were timely adopted to raise the crop successfully. Ten randomly selected plants from each replication were utilized for recording observations of physical characters viz., days to maturity, curd height $(\mathrm{cm})$, curd weight $(\mathrm{kg})$, curd solidity and curd yield ( $\mathrm{t} / \mathrm{ha}$ ). The individual genotype which exhibited the superior performance both in hills and plains were selected and compared them for biochemical characters like Moisture content, acidity, ascorbic acid, protein, phosphorus, calcium and potassium. The moisture content of cabbage was determined by using a digital moisture meter model manufactured by Ohaus (Model MB 45). Acidity of cabbage was determined by titration with standard sodium hydroxide $(0.1 \mathrm{~N})$ and expressed as per cent of citric acid as per Ranganna (1997). Ascorbic acid content of cabbage was estimated by 2, 6 dichlorophenol indophenol dye method. The protein content of cabbage was determined by Lowry's method. The phosphorus content was analyzed colorimetrically as suggested by Jackson (1973), which give yellow colour with nitric acid vanadate molybdate reagent. Calcium content was estimated by Atomic Absorption Spectrophotometer from digested sample of cabbage. Similarly, potassium content was estimated by using flame photometer as suggested by Jackson (1973). Like $5 \mathrm{ml}$ of digested sample was made up to $50 \mathrm{ml}$ and read directly in flame photometer and potassium content was expressed in $\mathrm{mg}$ per $100 \mathrm{~g}$.

\section{RESULT AND DISCUSSION}

Among the cabbage genotypes, NS 183 was found to be the best for hilly region in terms of higher head yield $(22.06 \mathrm{Kg} / 16 \mathrm{~m} 2)$, head weight $(729.6 \mathrm{~g})$, head height $(11.1 \mathrm{~cm})$ and early yield. The cabbage genotype Tropical Sun Plus exhibited better performance in plains in terms of higher head yield $(22.06 \mathrm{Kg} / 16 \mathrm{~m} 2)$, head weight $(729.6 \mathrm{~g})$ and head height $(11.1 \mathrm{~cm})$. The individual genotype which exhibited the superior performance in hills and plains were selected and compared the general biochemical characters (Table 1). The constituents analysed were moisture, acidity, ascorbic acid, protein and minerals (phosphorus, calcium and potassium). Cabbage genotype, TSP recorded $90.59 \%$ of higher moisture content when grown in plains $(85.63 \%)$ as compared to hills. Similar changes of moisture content were also noticed in NS 183 recorded $87.69 \%$ and $89.86 \%$ grown under hills and plains respectively (Table 2.). Likewise, NS $183(0.144 \%)$ from hills recorded higher acidity content than NS $183(0.104 \%)$ from plains. The acidity of cabbage genotypes TSP from hills and plains was $0.120 \%$ and $0.071 \%$ respectively. Haque et al. (2005) suggested that titratable acidity of cabbage depends on the time of planting, cultivars and location. Therefore altitude may influence the acidity of cabbage grown under different locations.

Significantly higher content of ascorbic acid was observed in hill grown TSP (42.6 mg/ $100 \mathrm{~g})$ compared to plain grown TSP $(12.92 \mathrm{mg} / 100 \mathrm{~g})$. The ascorbic acid of NS 183 from hills and plains was 51.80 and $17.92 \mathrm{mg} / 100 \mathrm{~g}$ respectively. Martinez et al. (2010) suggested that ascorbic acid content varied according to the cultivars and location specific. Similar kinds of observations were also reported by Kadam et al. (2008) and Abusalem (2007). There was noticed significant reduction in ascorbic acid content when during storage. After one week of storage considerable reduction in 
ascorbic acid content, which were $37.67 \mathrm{mg} / 100 \mathrm{~g}$ and $31.48 \mathrm{mg} / 100 \mathrm{~g}$ in hills grown NS 183 and TSP respectively. Lee and Kader (2000) and Podsedek (2007) reported that ascorbic acid is very sensitive to storage condition and it varied depending on temperature, humidity, oxygen and carbon dioxide content. Similarly, Opatova et al. (2003) suggested that retention of ascorbic acid varied from 50 to $70 \%$ and the losses increased when storage duration is increases.

Significant variation was observed in protein content where between hill and plains grown TSP is $0.80 \mathrm{~g} / 100 \mathrm{~g}$ and $0.65 \mathrm{~g} / 100 \mathrm{~g}$ respectively. Similarly, hill grown NS 183 recorded higher protein content than plain grown NS 183. According to Srisangnam et al. (2007) the higher leaf protein content may due to prevailing favorable climate particularly rainfall and better irrigation or due to the residual effect of soil nutrients from previous growing season. Phosphorus content was comparatively high in NS 183 grown in hills are $16.20 \mathrm{mg} / 100 \mathrm{~g}$. Similarly, TSP grown in hill was containing more amount of Phosphorus than plains. Cabbage genotype TSP from plains recorded higher calcium content $(110.02 \mathrm{mg} / 100 \mathrm{~g})$ than hills $(73.03 \mathrm{mg} / 100 \mathrm{~g})$. No significant difference was observed in case of potassium content between hill and plains grown genotypes NS 183 and TSP. Similar kinds of observation were also noticed by Watt and Wood (1963). Therefore, NS 183 and Tropical Sun Plus grown under hills were found to be a superior in nutritive value with higher content of vitamin $\mathrm{C}$ and minerals like phosphorus and potassium.

\section{CONCLUSION}

The biochemical constituents (moisture, acidity, ascorbic acid, protein and minerals) of the best performing genotypes identified both from hills and plains in cabbage were analysed. The cabbage genotype NS 183 from hills recorded comparatively higher values of biochemical constituents like acidity $(0.144 \%)$, ascorbic acid $(51.80 \mathrm{mg} / 100 \mathrm{~g})$, protein $(0.73 \mathrm{~g} / 100 \mathrm{~g})$, phosphorus (26.23 mg/100g) and potassium (200.23 mg/100g). Similarly, Tropical Sun Plus from hills also recorded the higher value of biochemical constituent. In recent past cultivation of cabbage extended to plains of Kerala, India also. In view of above finding genotype, Tropical Sun Plus is performing well in both plains and hills of Kerala as compared to NS 183 and also it having considerable value of biochemical constituent which is more immense value to the farming community.

\section{Acknowledgment}

The Authors express their primary thanks to Indian Council of Agriculture Research for providing JRF for this study. The Authors express their secondary thanks to Department of Processing Technology (Horticulture), College of Horticulture, Kerala Agriculture University, Vallanikara, Thrissur and Department of Horticulture, Agriculture Research Station, Mannuthy, Thrissur (680656), Kerala for successfully completion of work. 
Table 1. Biochemical characteristics of Tropical Sun Plus grown in hills and plains

\begin{tabular}{|c|c|c|c|c|}
\hline $\begin{array}{c}\text { Sl. } \\
\text { No. }\end{array}$ & Characters & TSP from hills & TSP from plains & t value \\
\hline 1 & Moisture content (\%) & 85.63 & 90.59 & $3.4468^{* *}$ \\
\hline 2 & Acidity (\%) & 0.120 & 0.071 & $7.9623^{* *}$ \\
\hline 3 & Ascorbic acid (mg/100g) & & & \\
\cline { 2 - 5 } & i) Before storage & 42.60 & 12.92 & $21.650^{* *}$ \\
\cline { 2 - 5 } & ii) After one week of & 31.48 & 9.17 & $24.501^{* *}$ \\
\hline 4 & storage & & & $2.3214^{* *}$ \\
\hline 5 & Phosphorus (mg/100g) & 28.04 & 14.65 & $41.041^{* *}$ \\
\hline 6 & Calcium $(\mathrm{mg} / 100 \mathrm{~g})$ & 73.03 & 110.02 & $31.9645^{* *}$ \\
\hline 7 & Potassium $(\mathrm{mg} / 100 \mathrm{~g})$ & 202.13 & 197.15 & Ns \\
\hline
\end{tabular}

** Significant

Ns- Non significant

Table 2. Biochemical characteristics of NS 183 grown in hills and plains

\begin{tabular}{|c|c|c|c|c|}
\hline $\begin{array}{c}\text { Sl. } \\
\text { No. }\end{array}$ & Characters & $\begin{array}{c}\text { NS } 183 \text { from } \\
\text { hills }\end{array}$ & $\begin{array}{c}\text { NS 183 from } \\
\text { plains }\end{array}$ & t value \\
\hline 1 & Moisture content (\%) & 87.69 & 89.86 & $2.3254^{* *}$ \\
\hline 2 & Acidity (\%) & 0.144 & 0.104 & $5.1230^{* *}$ \\
\hline \multirow{2}{*}{3} & Ascorbic acid $(\mathrm{mg} / 100 \mathrm{~g})$ & & & \\
\cline { 2 - 5 } & i) Before storage & 51.80 & 7.92 & $21.660^{* *}$ \\
\cline { 2 - 5 } & ii) After one week of & 37.67 & 7.17 & $24.561^{* *}$ \\
\hline 4 & storage & 0.73 & 0.84 & $1.5452^{* *}$ \\
\hline 5 & Photein $(\mathrm{g} / 100 \mathrm{~g})$ & 26.23 & 16.20 & $31.045^{* *}$ \\
\hline 6 & Calcium $(\mathrm{mg} / 100 \mathrm{~g})$ & 42.41 & 76.00 & $36.505^{* *}$ \\
\hline 7 & Potassium $(\mathrm{mg} / 100 \mathrm{~g})$ & 200.23 & 183.14 & Ns \\
\hline
\end{tabular}

** Significant

Ns- Non significant

\section{Abbreviation:}

TPS- Tropical Sun Plus

NS- Namdhari Seeds

Ns- Non significant

\section{Reference}

[1] Abusalem, F.M., Hassan, F.R.H., Elwaseif, K.H.M and Ghada, M.M. 2007. Effect of blanching processes of some vegetables on ascorbic acid, carotenoids and iron. Ann. Agric. Sci. Cairo., 52(2): 357-366.

[2] Haque, K.M.F., Jahangir, A.A., Haque, M.E., Mondal, R.K., Jahan, M.A.A and Sarker, M.A.M. 2005. Influence of variety and time of planting on the yield performance and nutrient contents of cabbage (Brassica oleracea L.). Bangladesh J. Sci. Ind. Res., 40(3/4): 211-218.

[3] Jackson, M.L. 1973. Soil Chemical Analysis, Prentice-Hall of India Pvt. Ltd, New Delhi, India, pp. 1-50.

[4] Jagdish, S., Upadhyay, A.K., Singh, S and Rai, M. 2009. Total phenolics content and free scavenging activity of Brassica vegetables. J. Fd Sci. Technol., 46(6): 595- 597. 
[5] Kadam, D.M., Samuel, D.V.K., Chandra, P and Sikarwar, H.S. 2008. Impact of processing treatments and packaging material on some properties of stored dehydrated cauliflower. Int. J. Fd Sci. Technol. 43(1): 1-14.

[6] Lee, S.K and Kader, A.A. 2000 Preharvest and postharvest factors influencing vitamin C content of horticultural crops. Postharvest Biol. Technol., 20: 207-220.

[7] Martinez, S., Olmos, I., Carballo, J and Franco, I. 2010. Quality parameters of Brassica spp. grown in Northwest Spain. Int. J. FD Sci. Technol., 45(4): 776-783.

[8] NHB [National Horticulture Board]. 2014. NHB home page [online]. Available: http://nhb.gov.in. [07 $7^{\text {th }}$ June 2014].

[9] Opatova, H., Sevcik, R., Dufkova, M., and Prodelal, R. 2003. Efficacy of decontamination methods on minimally processed vegetables. Acta Hort., 600: 599- 602.

[10] Podsedek, A. 2007. Natural antioxidants and antioxidant capacity of Brassica vegetables: a review. Fd Sci. Technol., 40: 1-11.

[11] Ranganna, S. 1997. Handbook of Analysis and Quality Control for Fruits and Vegetable Products ( ${ }^{\text {rd }}$ Ed.) Tata Mc Graw and Hill Publication Co. Ltd., New Delhi. 634p.

[12] Singh, B.K., Sharma, S.R., Kalia, P and Singh, B. 2010. Character association and path analysis of morphological and economic traits in cabbage. Indian J. Agric Sci. 80: 116-18.

[13] Srisangnam, C., Reddy, N.R., Salunkhe, D.K and Dull, G.G. 2007. Quality of cabbage part III: Effect of blanching on the nutritional quality of cabbage (Brassica oleracea L.) proteins. J. Fd Quality. 3: 251-259.

[14] Watt, B.K and Wood, A.L. 1963. Nutritive value of fruits and vegetable. USDA handbook Publisher, Yamaguchi. 8p. 